\title{
Gasification characteristics of hydrochar and pyrochar derived from sewage sludge
}

\author{
Chao Gai ${ }^{a}$, Mengjun Chen ${ }^{b}$, Tingting Liu ${ }^{a}$, Nana Peng ${ }^{a}$, Zhengang Liu ${ }^{\text {a, * }}$ \\ ${ }^{a}$ Research Center for Eco-Environmental Sciences, Chinese Academy of Sciences, 18 Shuangqing Road, Beijing 100085, PR China \\ ${ }^{\mathrm{b}}$ Key Laboratory of Solid Waste Treatment and Resource Recycle, Ministry of Education, Southwest University of Science and Technology (SWUST), 59 \\ Qinglong Road, Mianyang 621010, PR China
}

\section{A R T I C L E I N F O}

\section{Article history:}

Received 31 March 2016

Received in revised form 5 July 2016

Accepted 24 July 2016

Available online 2 August 2016

\section{Keywords:}

Hydrothermal carbonization

Pyrolysis

Biochar

Waste biomass

Hydrogen

Steam gasification

\begin{abstract}
A B S T R A C T
Two types of the biochars, pyrochar and hydrochar derived from low temperature pyrolysis (LTP) and hydrothermal carbonization (HTC) of sewage sludge were prepared and characterized. Their gasification properties were further experimentally evaluated. The results showed that the hydrochar was more hydrophobic than the pyrochar. The hydrochar was rich in nitrogen-containing functional groups and increased nickel, iron, alkali and alkaline earth metallic species compared to the raw sludge and pyrochar. It enhanced the interactions between the carbon surface and hydrogen bonding as well as gasification reactivity of the hydrochar, thus resulting in a higher hydrogen concentration and yield than the pyrochar under identical conditions. Additionally, the hydrochar had a more porous structure on the surface, facilitating the pores better accessible for condensable hydrocarbon molecules and thus improved the gas production and gasification efficiency. Although the energy recovery efficiency of LTP-gasification method was higher than that of HTC-gasification approach, the total energy consumption during the HTC pretreatment combined with subsequent gasification was lower than the energy evolved in the corresponding product gas in most gasification conditions. This study demonstrates that the integration of HTC pretreatment and subsequent gasification has promising potential for hydrogen-rich syngas production from sewage sludge.
\end{abstract}

๑) 2016 Elsevier Ltd. All rights reserved.

\section{Introduction}

The depletion of fossil-fuel reserves and increasing environmental pollution caused by the large-scale application of fossil fuel make hydrogen an attractive alternative energy carrier and for the production of chemical products (e.g., methanol, ammonia) [1]. Currently, hydrogen is mostly generated from steam reforming of natural gas for industrial application. To achieve the goal of sustainable hydrogen production, the dependence away from fossilfuel to renewable alternatives, such as biomass resources, is a step in the right direction [2]. As a byproduct from municipal or industrial wastewater treatment processes, sewage sludge is a kind of abundant waste biomass, which contains large amounts of organic components. Until recently, sewage sludge is usually disposed by landfill or incineration, which suffers from secondary pollution and low energy recovery rate [3].

\footnotetext{
* Corresponding author.

E-mail address: zgliu@rcees.ac.cn (Z. Liu).
}

Green Chemistry aspires to reduce consumption of nonrenewable resources and at the same time produce high-quality products in an environmental-friendly manner from renewable resources. Gasification of sewage sludge may be one of the promising sustainable approaches for hydrogen-rich syngas production. However, raw sludge is unsuitable for direct gasification due to the high water content and thus pretreatment is necessary to improve its quality prior to further gasification process [4]. Applying proper thermochemical pretreatment can also improve the energy efficiency and diversify the energy utilization pathways.

As one of the typical thermochemical pretreatment, low temperature pyrolysis (LTP) $[5,6]$ converts biomass into pyrochar under an inert atmosphere with low heating rate. The pyrochar has improved physical and chemical characteristics, and it has been extensively used for soil amendment, wastewater pollution remediation, carbon sequestration and bioenergy production [7]. An alternative to LTP is hydrothermal carbonization (HTC) [8-10], which converts biomass into hydrochar in aqueous phase under facile temperatures and self-generated pressure. HTC offers several potential advantages such as high conversion efficiency and the 
ability to use diverse feedstock without drying pretreatment, which is especially suitable for high water content of biomass like sewage sludge.

The physical properties and chemical functionalities on the surface of the pyrochar and hydrochar are significantly different from each other, both of which thus have respective advantages in various industry applications. Escala et al. [11] reported that conducting HTC and drying the hydrochar have energetic advantages compared with drying the sewage sludge for thermal disposal treatment. In addition, the HTC-pretreated sewage sludge is reported to have improved combustion properties compared to the pyrochar and raw sludge $[6,9,12,13]$. In terms of gasification of the biochar, Álvarez-Murillo et al. [5] studied the steam gasification characteristics of the hydrochar derived from olive stone as a representative of lignocellulosic biomass. It was observed that the hydrochar modified the gas profiles during gasification, improving $\mathrm{H}_{2}$ and $\mathrm{CO}$ production as well as the heating value. Erlach et al. [14] also concluded that pretreating the lingocellulosic biomass with HTC produced a hydrochar that was better suited for entrained flow gasification than raw biomass. These studies successfully verified the improved gasification behavior of lignocellulosic biomass after the hydrothermal pretreatment.

Different from lignocellulosic biomass (mainly composed of biopolymers cellulose, hemicellulose and lignin), the main composition of sewage sludge is protein and lipid. Therefore, different gasification behavior of hydrochar derived from sewage sludge is expected to that of the hydrochar from lignocellulosic biomass. Our previous study [15] investigated the gasification behavior of the hydrochar derived from sewage sludge by hydrothermal carbonization. It was observed that compared to the raw material, the hydrothermally treated sewage sludge had improved gasification characteristics in terms of hydrogen-rich syngas production. However, the lack of understanding on the effect of different pretreatments on the gasification behavior of the same sewage sludge under identical conditions is making the investigation on thermochemical treatment of sewage sludge difficult to go to a more profound level. Therefore, the primary goal of this study is to investigate the gasification properties of pyrochar and hydrochar derived from sewage sludge by LTP and HTC, respectively. Previous literature [16-18] have shown that steam as the gasifying medium has been proved effective for enhancing hydrogen yield compared to air gasification or air-steam gasification. In this work, the effects of operating conditions, including reaction temperature and the mass ratio of steam to biomass on gasification characteristics of the pyrochar and hydrochar were experimentally evaluated in terms of gas composition, heating value, gasification efficiency and energy recovery efficiency.

\section{Experimental section}

\subsection{Biochars preparation}

Sewage sludges were collected from a municipal sewage treatment plant in Beijing, China. The collected raw sludge still contains high content of water. Prior to the LTP reaction, the raw sludge was centrifuged, oven dried at $105{ }^{\circ} \mathrm{C}$ for $12 \mathrm{~h}$ and then ground into powders. However, no dewatering and drying pretreatment was conducted for the HTC treatment.

Reaction temperature and retention time are two significant factors affecting the properties of the biochars. A recent study [19] investigated the effect of temperature $\left(180-250^{\circ} \mathrm{C}\right)$ on the characteristic of hydrochar derived from anaerobically digested sludge, and it was concluded that $220{ }^{\circ} \mathrm{C}$ was the optimal reaction temperature with the highest energy recovery efficiency (93.1\%). Danso-Boateng et al. [20] evaluated the kinetics of HTC of different biomass, and it was reported that temperature had a more pronounced effect on hydrochar production than retention time and increasing the retention time beyond $1 \mathrm{~h}$ did not significantly improve hydrochar yield. Therefore, for both fundamental and practical interests, we used a temperature of $220{ }^{\circ} \mathrm{C}$ and retention time of $1 \mathrm{~h}$ for the hydrochar production.

Hydrochar of sewage sludge was prepared using a stainless autoclave. A feedstock slurry of raw sludge with DI water was loaded into the reactor and kept the solid:liquid ratio of $1: 9(\mathrm{w} / \mathrm{w})$. The reactor was sealed and heated to $220^{\circ} \mathrm{C}$ for $1 \mathrm{~h}$, and the corresponding pressure at final reaction was $1.9 \mathrm{MPa}$. Then the reactor was rapidly cooled down to room temperature by flowing tap water. Solid hydrochar produced from HTC was separated from the resultant mixture by centrifugation, and was oven dried at $105{ }^{\circ} \mathrm{C}$ for $12 \mathrm{~h}$ before the subsequent gasification test.

To make a comparison, the pyrochar derived from sewage sludge was produced under the same temperature (i.e., $220^{\circ} \mathrm{C}$ ) by the approach of LTP. The LTP experiment was conducted in a quartz tubular reactor under atmospheric pressure. Five grams ( $5 \mathrm{~g})$ of the dried sewage sludge were packed in the middle of the reactor and then heated by an electric furnace under a constant $\mathrm{N}_{2}(99.9 \%)$ flowing of $200 \mathrm{ml} / \mathrm{min}$. After being held at $220{ }^{\circ} \mathrm{C}$ for $1 \mathrm{~h}$, the electric furnace was turned off and the samples were cooled to ambient temperature. All the LTP and HTC experiments were conducted in duplicates. The pyrochar and hydrochar derived from sewage sludge were both ground into powders less than $0.5 \mathrm{~mm}$ for the characterization and subsequent steam gasification experiments.

\subsection{Steam gasification experiments}

Steam gasification of the pyrochar and hydrochar was carried out in a laboratory-scale fixed-bed reactor system [15]. It is mainly composed of a quartz tubular reactor, steam generation kit, $\mathrm{N}_{2}$ line, and a gas purification unit. The inner diameter and length of the quartz tube are $60 \mathrm{~mm}$ and $1000 \mathrm{~mm}$, respectively. Schematic illustration of biochar preparation and steam gasification for the production of hydrogen-rich syngas is shown in Fig. 1.

As the beginning of each test, $1 \mathrm{~g}$ of feedstock was weighed and then placed onto the quartz boat. Nitrogen (99.9\%) with a flow rate of $100 \mathrm{ml} / \mathrm{min}$ was fed to the reactor to produce an anoxic atmosphere. The quartz tube was heated to the desired temperatures by an electric furnace, followed by turning on the steam generation kit. After $20 \mathrm{~min}$, the quartz boat was injected into the heating zone of the tube by the rod, and the nitrogen gas was switched off. The produced gas passed through the gas purification unit to remove tar and water, then the clean, cool and dry gas was collected using a gas sampling bag in the entire reaction time. The main gas composition $\left(\mathrm{H}_{2}, \mathrm{CH}_{4}, \mathrm{CO}, \mathrm{CO}_{2}\right)$ was analyzed using a gas chromatograph (GC 3420A) equipped with a thermal conductivity detector (TCD) and two columns, including 5A and GDX-104. Argon was adopted as the carrier gas, and standard gas mixtures were applied for quantitative calibration. Gasification characteristics of the pyrochar and hydrochar were evaluated in terms of hydrogen yield, lower heating value (LHV) of the product gas and gasification efficiency [15,21]. Besides, an index of energy recovery efficiency (ERE) [22] was used in this work to evaluate the effect of two different pretreatments on the entire energy balance, which is calculated as:

$E R E_{\text {Pre }}^{i}=\frac{H H V_{\text {biochar }}^{i} \times W_{\text {biochar }}^{i}}{H H V_{\text {dry sludge }} \times W_{\text {dry sludge }}}$ 


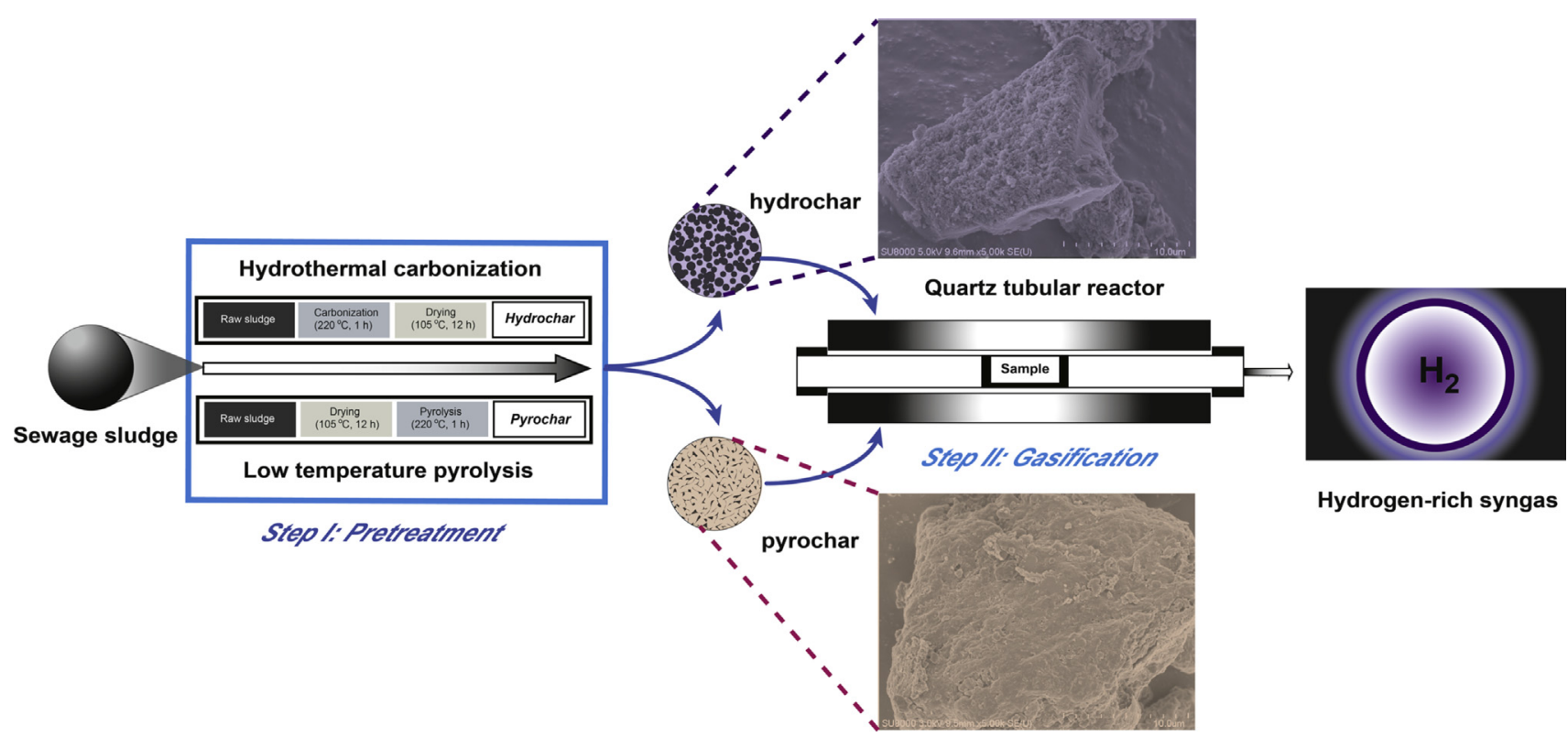

Fig. 1. Schematic illustration of preparation of the two biochars and steam gasification of biochars for the production of hydrogen-rich syngas.

$E R E_{\text {Gas }}^{i}=\frac{H H V_{\text {syngas }} \times Y_{\text {syngas }}^{i}}{H H V_{\text {biochar }} \times W_{\text {biochar }}^{i}}$

$E R E_{\text {Total }}^{i}=E R E_{\text {Pre }}^{i} \times E R E_{\text {Gas }}^{i}$

Where ERE $E_{\text {Pre }}$ is the energy recovery efficiency of the pretreatment; $E E_{\text {gas }}$ is the energy recovery efficiency of the gasification process; $E E_{\text {total }}$ is the energy recovery efficiency of the total conversion process; The value of $i$ means the pretreatment approach of LTP or HTC; $\mathrm{HHV}_{\text {biochar }}$ is the higher heating value of biochar, $\mathrm{MJ} / \mathrm{kg}$; $\mathrm{HHV}_{\text {dry sludge }}$ is the higher heating value of dry sludge, $\mathrm{MJ} / \mathrm{kg}$; $\mathrm{HHV}_{\text {syngas }}$ is the higher heating value of syngas, $\mathrm{MJ} / \mathrm{Nm}^{3} ; \mathrm{W}_{\text {biochar }}$ is the weight of biochar, $\mathrm{kg}$; $W_{\text {dry sludge }}$ is the weight of dry sludge, $\mathrm{kg}$; $\mathrm{Y}_{\text {syngas }}$ is the gas yield, $\mathrm{Nm}^{3} / \mathrm{kg}$.

Gas composition and gasification characteristics are strongly impacted by reaction temperature and steam to biomass (S/B) mass ratio. In this study, the reaction temperature varied from 750 to $1050{ }^{\circ} \mathrm{C}$. The steam to biomass ratio ranged from 0.5 to 2.0 by changing the steam flow rate while holding the biomass weight for each experiment. All steam gasification experiments were conducted in triplicates and average values were reported.

\subsection{Biochars characterization}

Volatile matter and ash contents of the raw sludge, pyrochar and hydrochar were determined following standard ASTM D3175-07 and ASTM D3174-12. Elemental analysis (C, H, N, S) was conducted on an elemental analyzer (CE-440, Exeter Analytical Inc., North Chelmsfor, MA), and oxygen content was determined by difference. The higher heating value (HHV) of the raw sludge, pyrochar and hydrochar were determined by a bomb calorimeter (Model 1281, Parr Instrument Co., USA). The absolute concentration of inorganic elements ( $\mathrm{Ni}, \mathrm{Fe}, \mathrm{K}, \mathrm{Na}, \mathrm{Ca}, \mathrm{Mg}, \mathrm{Si}, \mathrm{Al}, \mathrm{Cu}, \mathrm{Zn}, \mathrm{Ti}$ ) in the pyrochar and hydrochar were determined by Inductively Coupled Plasma Optical Emission Spectroscopy (ICP-OES). The procedure involved a digestion of sample $(0.1 \mathrm{~g})$ in a $\mathrm{HNO}_{3} / \mathrm{H}_{2} \mathrm{O}_{2} / \mathrm{HClO}_{4} / \mathrm{HF}$ mixture (2:2:1:2), and the solution was analyzed by ICP-AES (Leeman Prodigy, USA). A scanning electron microscope (SEM, HR-FE-SEM
SU8020, HITACHI, Japan) was applied to observe the surface morphologies of the pyrochar and hydrochar samples. Fourier Transform Infrared Spectroscopy (FTIR, Thermo Nicolet Nexus 670, USA) was used to characterize surface functional groups of the samples.

\section{Results and discussion}

\subsection{Biochars characteristics}

\subsubsection{Chemical composition}

The properties of the pyrochar and hydrochar depend to a large extent on the chemical compositions, which are shown in Table 1. Proximate analysis illustrated that compared to raw sludge, the amounts of volatile matter (VM) of the pyrochar and hydrochar both decreased while the contents of fixed carbon (FC) and ash both increased. It is mainly attributed to the devolatilization of VM and polymerization during the pyrolysis/hydrothermal process. For the pyrochar and hydrochar, the loss of VM was higher than the increased FC, indicating that VM was converted to other gaseous products (e.g. $\mathrm{CO}_{2}$ ) or liquid. The higher heating value of the hydrochar $(16.21 \mathrm{MJ} / \mathrm{kg}$ ) was higher than that of the pyrochar (14.72 $\mathrm{MJ} / \mathrm{kg}$ ) and raw sludge (13.17 $\mathrm{MJ} / \mathrm{kg}$ ).

Elemental analysis illustrated that the carbon content of the pyrochar and hydrochar was higher than that of the raw sludge.

Table 1

Proximate and ultimate analysis of the sewage sludge, pyrochar and hydrochar.

\begin{tabular}{|c|c|c|c|}
\hline Strain & Sewage sludge & Pyrochar & Hydrochar \\
\hline \multicolumn{4}{|c|}{ Proximate analyses (\%, dry basis) } \\
\hline FC & 11.46 & 13.71 & 15.68 \\
\hline VM & 57.78 & 49.01 & 31.74 \\
\hline Ash & 30.76 & 37.28 & 52.58 \\
\hline \multicolumn{4}{|c|}{ Ultimate analyses (\%, dry ash free basis) } \\
\hline $\mathrm{C}$ & 33.98 & 39.36 & 43.58 \\
\hline $\mathrm{H}$ & 6.02 & 4.37 & 4.79 \\
\hline $\mathrm{N}$ & 6.24 & 7.97 & 9.52 \\
\hline $\mathrm{O}^{\mathrm{a}}$ & 52.84 & 45.58 & 42.63 \\
\hline$S$ & 0.92 & 1.17 & 1.03 \\
\hline HHV (MJ/kg) & 13.17 & 14.72 & 16.21 \\
\hline
\end{tabular}

\footnotetext{
a By difference.
} 
More aromatic carbon structures are formed during the pyrolysis, resulting in an increased carbon content of the pyrochar [23,24]. In case of the hydrochar, the increased carbon content is because a significant fraction of carbon retained within the hydrochar after the HTC process [25]. In the case of hydrogen content, it decreased for the pyrochar and hydrochar as expected with dehydration reactions, which is one of the principal reactions occurring under thermochemical conditions. For instance, the cleavage (dehydroxylation) of phenolic and alcohol functional groups were reported at $150{ }^{\circ} \mathrm{C}$ and $200{ }^{\circ} \mathrm{C}$ respectively during HTC of lignin [26]. The oxygen content of the hydrochar was lower than that of the pyrochar and raw sludge. The result is mainly attributed to the hydrolysis of the raw sludge into proteins and amino acids. According to Wiedner et al. [27], chemical property of hydrochar varied as a function of hydrothermal temperature and to a much lesser extent to feedstock, especially at lower carbonization temperature. Protein is the main organic fraction of sewage sludge. Sereewatthanawut et al. [28] extracted protein and amino acids from rice bran by subcritical water hydrolysis. It was observed that the protein yields increased slightly when the temperature was ranged from 100 to $160{ }^{\circ} \mathrm{C}$, while a significant increase of protein was observed when the temperature was above $180{ }^{\circ} \mathrm{C}$. Proteins are chains of amino acids held together by peptide bonds, which is a covalent chemical bond. Under hydrothermal condition of $220{ }^{\circ} \mathrm{C}$, the ionization constant of water $\left(K_{w}\right)$ increases from $1 \times 10^{-14}$ at ambient temperature to $7 \times 10^{-12}$ [29], thus increasing the concentration of hydrodium and hydroxide ions. In the presence of hydrodium and hydroxide ions in water, peptide bond will undergo chemical reactions. Specifically, the carbonyl carbon in peptide bond will be attacked by an electronegative atom, breaking the carbonyl double bond and forming small tetrahedral intermediates. It is the pathway of proteolysis. The small molecules like peptide fractions and amino acids derived from splitting of proteins will be further degraded to low molecular weight amine via decarboxylation. Carbon dioxide is produced from the carboxyl group during the decarboxylation of amino acids, and thus removing the oxygen from the raw sludge.

Álvarez-Murillo et al. [5] investigated the characteristics of hydrochar derived from lignocellulosic biomass (i.e. olive stone) at $220{ }^{\circ} \mathrm{C}$ for $20 \mathrm{~h}$. It was reported a reduction of about $40 \%$ of the oxygen content for the hydrochar while in this study, we observed a $20 \%$ decrease in oxygen content for the hydrochar derived from the sewage sludge. The difference may be due to the different biochemical composition of olive stone and sewage sludge. Rogalinski [30] investigated the hydrolysis kinetics of starch, cellulose (polysaccharides) and proteins (polypeptides). It was reported that the rate constants for amino acid formation was lower than that of glucose because the peptide bond in the protein is relatively more stable under hydrothermal conditions in comparison with the $\beta$ 1,4- and $\beta$-1,6-glycosidie linkages in cellulose and starch.

\subsubsection{Surface morphology and functional group}

Thermal/hydrothermal treatment is known to change the physical and surface functional groups of the feedstock [31]. SEM images of the raw sludge and two biochars were shown in Fig. 2(a)-(c). The raw sludge and pyrochar were both relatively smooth structured while the microstructure of the hydrochar was quite different. Porous and disintegrated structures can be seen in the hydrochar and different forms can be observed in terms of cracks and trenches with small microspheres.

The FTIR spectra for the raw sludge and two biochars were presented in Fig. 2(d). The absorbance peaks at $3320 \mathrm{~cm}^{-1}$ represent the $\mathrm{O}-\mathrm{H}$ stretching vibration in hydroxyl or carboxyl functional groups. Compared to the raw sludge, this peak became less intense for the pyrochar and hydrochar, which was due to the dehydration process. It is consistent with the decreased hydrogen content for the pyrochar and hydrochar (see Table 1). Absorbance peak between 3000 and $2800 \mathrm{~cm}^{-1}$ is ascribed to aliphatic carbon $-\mathrm{CH}_{\mathrm{x}}$ stretching vibration in terms of asymmetric $\left(2925 \mathrm{~cm}^{-1}\right)$ and symmetric $\left(2850 \mathrm{~cm}^{-1}\right)-\mathrm{C}-\mathrm{H}$ stretching of methylene groups. As for these two peaks, no significant difference was observed for the raw sludge and hydrochar, whereas this peak was increased for the pyrochar. The peaks at $1710 \mathrm{~cm}^{-1}$ and $1120 \mathrm{~cm}^{-1}$ are attributed to $\mathrm{C}=\mathrm{O}$ and $\mathrm{C}-\mathrm{O}$ stretching vibrations of ester bonds, and a decrease of the two peaks was observed for the pyrochar and hydrochar compared to the raw sludge. It verified the speculation of occurrence of proteolysis during the HTC process mentioned above. The observation in FTIR spectra confirmed that the carboxyl and carbonyl groups were rapidly degraded above $150^{\circ} \mathrm{C}$ [32]. The band at $1645 \mathrm{~cm}^{-1}$ is ascribed to the stretching vibration of $-\mathrm{C}=\mathrm{O}$ in ketone groups. The band at $1540 \mathrm{~cm}^{-1}$ is assigned to the asymmetric stretching of $-\mathrm{C}=\mathrm{O}$ in carboxylic groups. As for the two bands, no prominent fluctuation was observed for the raw sludge and pyrochar, while a significant decrease was observed in that of the hydrochar. It verified the occurrence of decarboxylation in HTC process. Compared to the raw sludge and pyrochar, $\mathrm{N}-\mathrm{H}$ bending (1575-1525 $\left.\mathrm{cm}^{-1}\right)$ was observed in hydrochar, indicating the presence of amide compounds. Compared to the raw sludge, the pyrochar and hydrochar both showed a strong absorbance at $1455 \mathrm{~cm}^{-1}$, especially for the hydrochar, which is associated with the $-\mathrm{C}=\mathrm{C}$ stretching in aromatic ring carbons. The peaks at $1230 \mathrm{~cm}^{-1}$ and $835 \mathrm{~cm}^{-1}$ were also observed in the spectra of pyrochar and hydrochar, which are ascribed to the aromatic $\mathrm{C}-\mathrm{H}$ out-of-plane bending vibration, aromatic $\mathrm{CO}$ - and phenolic $-\mathrm{OH}$ stretching, respectively. The three peaks suggest that aromatization was occurred during the thermal/hydrothermal treatments at the selected temperature.

Overall, the oxygenated surface functional groups for the pyrochar and hydrochar were both decreased, which is consistent with the decrease in the oxygen content of the pyrochar and hydrochar (see Table 1). Aliphatic $\mathrm{C}-\mathrm{H}$ functional groups were dominated in the pyrochar while more aromatic $\mathrm{C}-\mathrm{H}$ functional groups were formed in the hydrochar. This confirms that the hydrochar is more hydrophobic than that of the pyrochar, which is consistent with the literature [33]. A difference in surface functionalities exists between the pyrochar and hydrochar, which in turn affect the subsequent gasification behavior and hydrogen-rich syngas production.

It should be noted that in this study the sewage sludge derived pyrochar had a low degree of aromaticity. McBeath et al. [34] analyzed cross-polarization (CP) and direct polarization (DP) spectra of pyrochar derived from chestnut wood. It was concluded that the aromaticity of pyrochar rapidly increases when temperature is above $400{ }^{\circ} \mathrm{C}$. Kambo et al. [12] also reported that the pyrochar produced around $350{ }^{\circ} \mathrm{C}$ was mainly dominated by aromatic (aryl) carbon with small fractions of alkyl-O and alkyl-C. A further increase of temperature over $500{ }^{\circ} \mathrm{C}$ may result in a completely conversion of alkyl-O and alkyl-C to aryl carbon. Therefore, pretreatment temperature can significantly affect the aromatic character of the biochar.

\subsection{Gasification performance}

\subsubsection{Evolution of the product gas composition}

Evolution of main composition of product gas ( $\mathrm{N}_{2}$ free and dry basis) in the steam gasification of the pyrochar and hydrochar as a function of temperature $\left(750-1050^{\circ} \mathrm{C}\right)$ was illustrated in Fig. 3. The $\mathrm{H}_{2}$ concentration strongly increased with increasing temperature from 750 to $950{ }^{\circ} \mathrm{C}$ for the pyrochar and hydrochar, but showed some decrease when the temperature was further increased to 

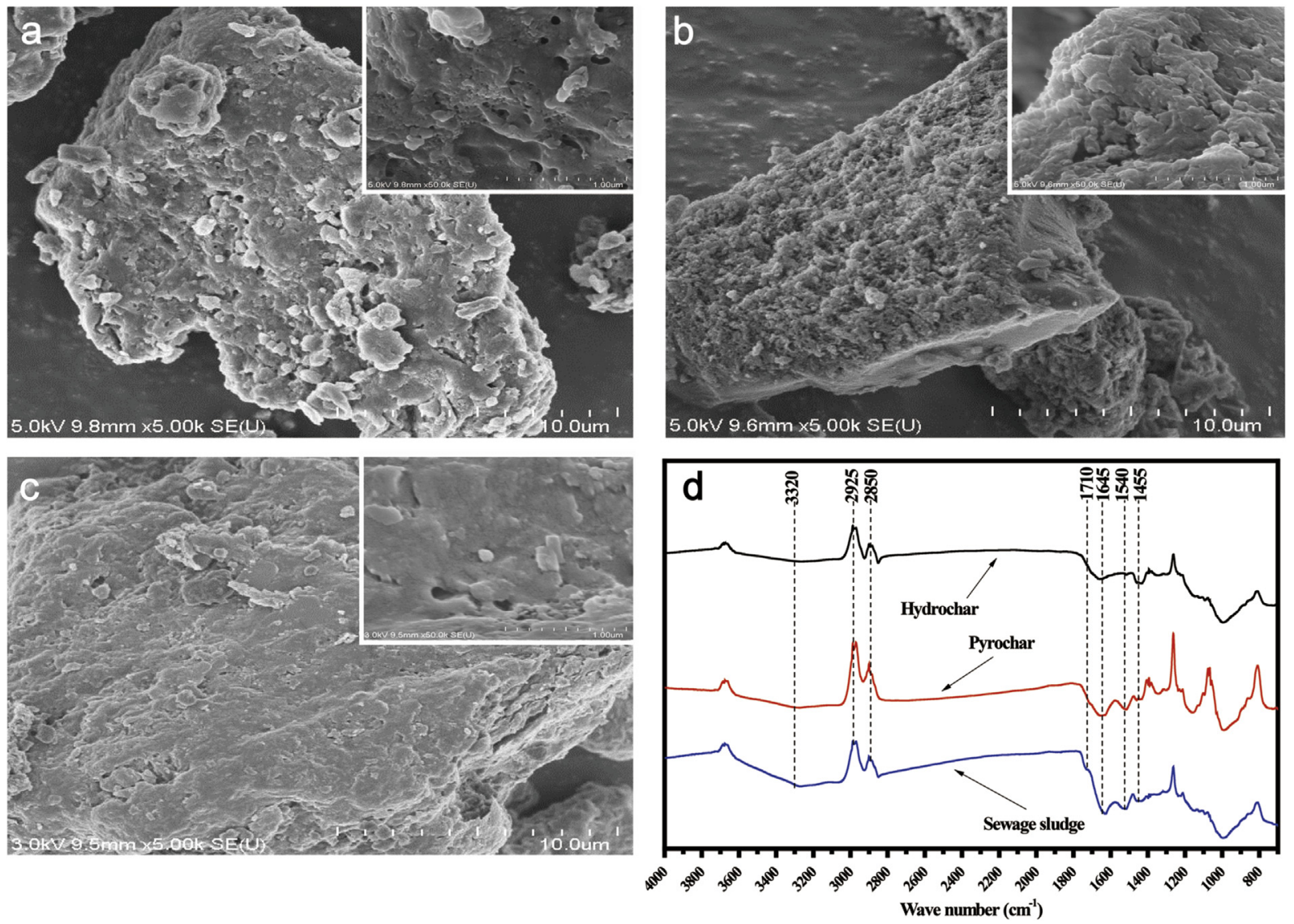

Fig. 2. Scanning electron microscope images of the sewage sludge (a), the pyrochar (b), and the hydrochar (c), (d) FTIR spectra of the pyrochar and hydrochar.

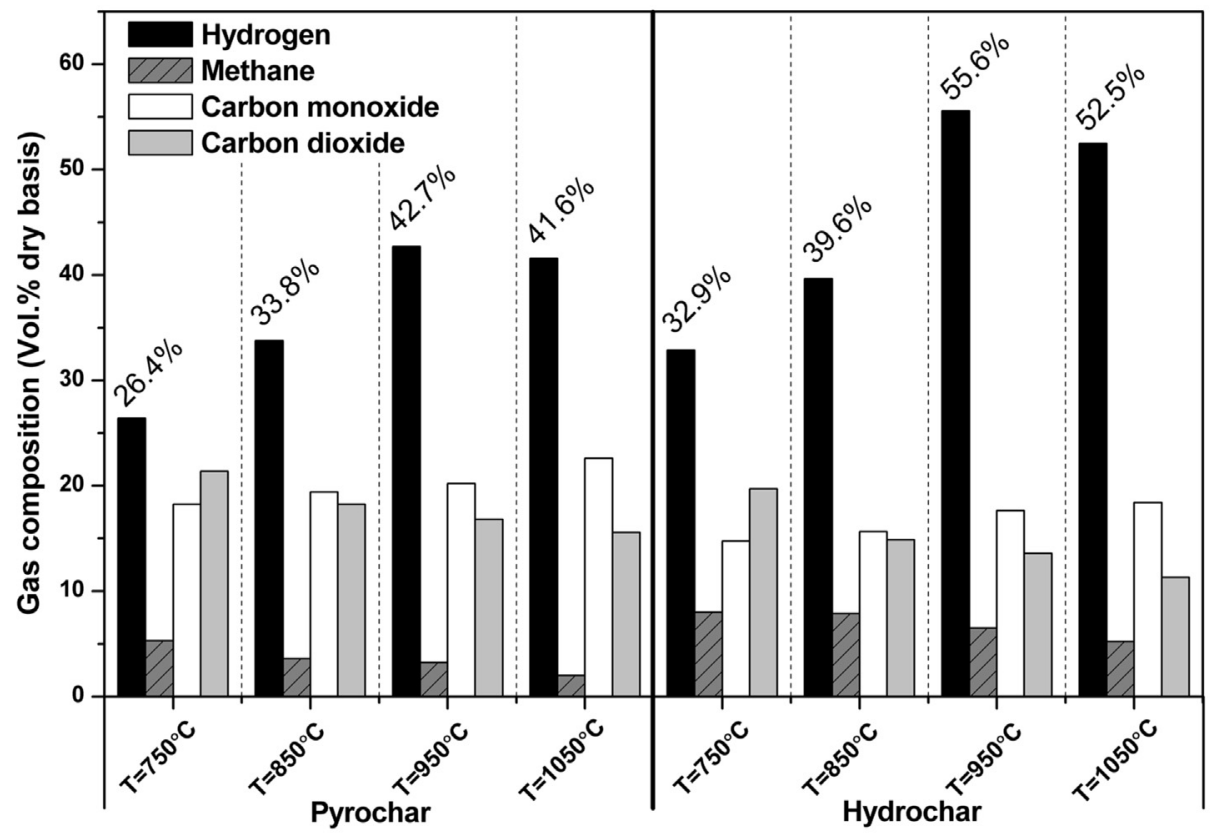

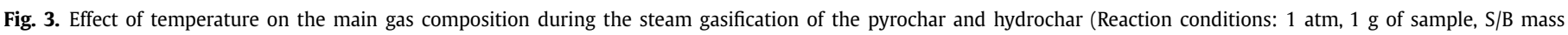
ratio $=0.5$ ).

$1050{ }^{\circ} \mathrm{C}$. The $\mathrm{CO}$ content was also found to increase continuously, while the $\mathrm{CO}_{2}$ and $\mathrm{CH}_{4}$ concentration decreased gradually. The higher temperature $\left(1050{ }^{\circ} \mathrm{C}\right)$ yielding a relative low $\mathrm{H}_{2}$ concentration is mainly due to the thermodynamic equilibrium limitations 
of endothermic water-gas shift (WGS) reaction in the steam gasification process. Based on WGS, an enhanced hydrogen concentration can be accomplished if $\mathrm{CO}_{2}$ is removed. For example, Stonor et al. [35] investigated the production of $\mathrm{H}_{2}$ from the steam gasification of cellulose with substantially suppressed $\mathrm{CO}_{2}$ formation using Group I and II hydroxides (e.g. $\mathrm{NaOH}, \mathrm{Ca}(\mathrm{OH})_{2}$ ) and a $\mathrm{Ni} / \mathrm{ZrO}_{2}$ catalyst. It was observed that the $\mathrm{H}_{2} / \mathrm{CO}_{2}$ ratios of the final gas products for $\mathrm{NaOH}$ and $\mathrm{Ca}(\mathrm{OH})_{2}+10 \% \mathrm{Ni} / \mathrm{ZrO}_{2}$ were 38 and 35 , both of which greatly outperformed stoichiometrically $\mathrm{H}_{2} / \mathrm{CO}_{2}$ ratio of 2 during cellulose gasification. Fermoso et al. [36] also reported that a high yield (80-93\%) of high purity hydrogen (99.9\%) was achieved by the addition of $\mathrm{Pd} / \mathrm{Ni}-\mathrm{Co}$ catalyst coupled with calcined dolomite as the $\mathrm{CO}_{2}$ acceptor in the steam gasification process of chestnut wood sawdust. In this study, the temperature between 950 and $1050{ }^{\circ} \mathrm{C}$ was observed to be a suitable operating window for obtaining high concentration $\mathrm{H}_{2}$ (over than $40 \mathrm{vol} \%$ for the pyrochar and 50 vol\% for the hydrochar).

Fig. 4 illustrated the effect of S/B mass ratio on the evolution of the gas product composition in the steam gasification of the pyrochar and hydrochar. The concentrations of $\mathrm{H}_{2}$ and $\mathrm{CO}_{2}$ for the pyrochar and hydrochar were increased first and then decreased while the content of $\mathrm{CO}$ and $\mathrm{CH}_{4}$ declined slightly with the increment of S/B ratio from 0.5 to 2.0. The decrease in $\mathrm{CH}_{4}$ concentration, however, was very slightly. A high S/B ratio favors WGS reaction for $\mathrm{H}_{2}$ and $\mathrm{CO}_{2}$ formation, and promotes the steam reforming of condensable hydrocarbons (tars) with high molecular weight. However, an excessive S/B ratio was observed to decrease the $\mathrm{H}_{2}$ concentration for the two biochars. It is probably due to the short residence time of the product gas with the increment of steam flow rate, result in a decrease of time in reactions between the steam and hydrocarbons. Klaas et al. [37] concluded that a longer residence time should be applied to maximize hydrogen production for the char steam reforming. Therefore, the optimum ratio of S/B for maximizing $\mathrm{H}_{2}$ concentration of the pyrochar and hydrochar in this study was 1.5 and 1.0 , respectively. Additionally, our results demonstrate that a proper $\mathrm{S} / \mathrm{B}$ ratio can be determined for enhancing hydrogen production. Stendardo et al. [17] and Lopez et al. [18] also reported that the composition of the syngas during gasification can be adjusted by verifying operating parameters such as temperature and gasifying medium (e.g., steam to oxygen/ feedstock weight ratio) for hydrogen production.

\subsubsection{Gasification characteristics}

Table 2 illustrated the gasification characteristics in terms of hydrogen yield, LHV, gasification efficiency and energy recovery efficiency. The hydrogen yields for pyrochar and hydrochar were greatly enhanced by the increased temperature and an S/B ratio of 1.0 can maximize the hydrogen yield of the pyrochar and hydrochar. Additionally, the hydrogen yield of gasification of hydrochar was always higher than that of pyrochar by $10-40 \%$ under identical gasification conditions. The maximum hydrogen yield (76.70 $\mathrm{g} \mathrm{H}_{2}$ / $\mathrm{kg}$ biochar) for hydrochar was achieved at an S/B ratio of 1.0 under the gasification temperature of $1050^{\circ} \mathrm{C}$. This yield is comparable to that of steam gasification of pine sawdust combined with porous ceramic reforming of syngas and $\operatorname{tar}$ (79.91 $\mathrm{g} \mathrm{H}_{2} / \mathrm{kg}$ biomass) [38].

The LHV of the pyrochar and hydrochar were also significantly affected by the reaction temperature and S/B mass ratio. The optimum temperature for maximizing LHV for the pyrochar $(8.32 \mathrm{MJ} /$ $\left.\mathrm{Nm}^{3}\right)$ and hydrochar $\left(10.55 \mathrm{MJ} / \mathrm{Nm}^{3}\right)$ were both $950{ }^{\circ} \mathrm{C}$, while at the temperature of $1050{ }^{\circ} \mathrm{C}$, the optimum S/B mass ratio for the pyro$\operatorname{char}\left(8.39 \mathrm{MJ} / \mathrm{Nm}^{3}\right)$ and hydrochar $\left(9.96 \mathrm{MJ} / \mathrm{Nm}^{3}\right)$ was both 1.0. LHV of the product gas is dependent on the gas composition, especially for $\mathrm{H}_{2}$ because the main combustible gas composition is hydrogen in this study. The variation of LHV as a function of temperature and S/B mass ratio was both consistent with the variation of gas composition shown in Figs. 3 and 4. Dissimilar with LHV, the gasification efficiency for the pyrochar and hydrochar were observed to be increased continuously as a function of temperature. It should be due to the favored thermal decomposition of condensable hydrocarbons at high temperatures. However, an excessive S/B mass ratio (i.e., higher than 1.0) was observed to decrease the gasification efficiency for the two biochars. It may be explained

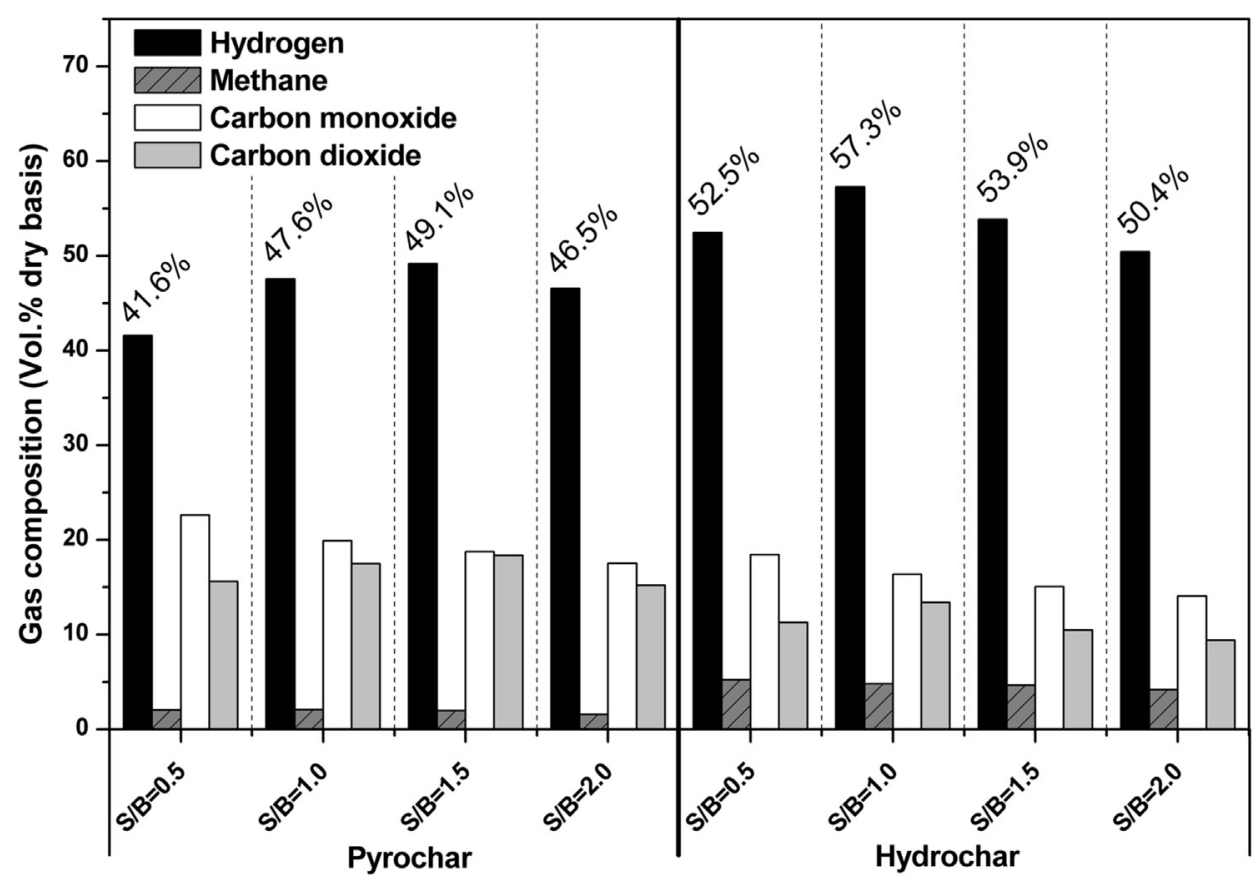

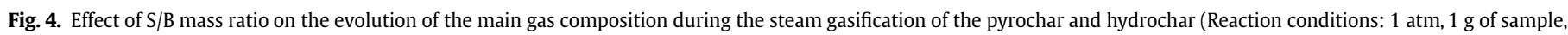
$\left.\mathrm{T}=1050{ }^{\circ} \mathrm{C}\right)$. 
Table 2

Gasification characteristics of the pyrochar and hydrochar.

\begin{tabular}{|c|c|c|c|c|c|c|c|c|}
\hline Experiment no. & & Run 1 & Run 2 & Run 3 & Run 4 & Run 5 & Run 6 & Run 7 \\
\hline Temperature $\left({ }^{\circ} \mathrm{C}\right)$ & & 750 & 850 & 950 & 1050 & 1050 & 1050 & 1050 \\
\hline S/B mass ratio & & 0.5 & 0.5 & 0.5 & 0.5 & 1.0 & 1.5 & 2.0 \\
\hline \multirow[t]{4}{*}{ Pyrochar } & Hydrogen yield ( $\mathrm{g} \mathrm{H}_{2} / \mathrm{kg}$ biochar) & 21.35 & 32.80 & 52.22 & 54.20 & 64.13 & 63.18 & 58.58 \\
\hline & LHV of product gas $\left(\mathrm{MJ} / \mathrm{Nm}^{3}\right)$ & 7.04 & 7.38 & 8.32 & 8.06 & 8.39 & 8.37 & 7.80 \\
\hline & Gasification efficiency (\%) & 42.11 & 52.22 & 74.31 & 75.85 & 82.98 & 80.89 & 72.33 \\
\hline & Energy recovery efficiency (\%) & 0.79 & 0.99 & 1.41 & 1.46 & 1.57 & 1.49 & 1.36 \\
\hline \multirow[t]{4}{*}{ Hydrochar } & Hydrogen yield ( $\mathrm{g} \mathrm{H}_{2} / \mathrm{kg}$ biochar) & 29.86 & 39.91 & 62.95 & 66.98 & 76.70 & 73.60 & 66.62 \\
\hline & LHV of product gas $\left(\mathrm{MJ} / \mathrm{Nm}^{3}\right)$ & 8.27 & 9.07 & 10.55 & 9.86 & 9.96 & 9.38 & 8.81 \\
\hline & Gasification efficiency (\%) & 49.69 & 61.72 & 79.75 & 80.64 & 87.95 & 82.01 & 74.11 \\
\hline & Energy recovery efficiency (\%) & 0.77 & 0.94 & 1.23 & 1.30 & 1.37 & 1.32 & 1.20 \\
\hline
\end{tabular}

by the fact that the residence time of reaction intermediates is shortened due to the increased steam flow rate, render an inhibition of steam evolved reactions. It should be noted that the gasification efficiency at a higher S/B mass ratio (i.e., higher than 1.0) for the two biochars were both higher than that of lower temperatures (i.e., lower than $1050{ }^{\circ} \mathrm{C}$ ). According to Palumbo et al. [39], increasing temperature would reduce the effect of kinetic limitation and promote the attainment of reaction equilibrium for gaseous products even for short residence time.

A ERE ${ }^{\mathrm{i}}$ Total of 1 means that the total energy consumption during the HTC/LTP pretreatment combined with subsequent gasification is equal to the energy evolved in the product gas. Table 2 illustrated that under identical condition, the ERE ${ }^{\mathrm{i}}$ Total of LTP was higher than that of HTC, implying that combining LTP and gasification is a more energy-saving approach for hydrogen-rich syngas production, compared with that of HTC-gasification method. Nevertheless, under identical condition, the HTC-gasification method can produce a syngas with higher yield and concentration of hydrogen. And for the Runs 3-7, the ERE ${ }_{\text {Total }}^{\mathrm{i}}$ of HTC-gasification method was higher than 1, implying that the total energy consumption during the HTC pretreatment combined with subsequent gasification is lower than the energy evolved in the product gas.

Under identical gasification conditions, the gasification characteristic of the hydrochar was observed to be better than that of the pyrochar. Gasification behavior is closely related to the inorganic matter in the feedstocks. The hydrochar was observed to have a higher ash content compared to the raw sludge and pyrochar (see Table 1). The contents of mineral elements in the raw sludge and two biochars were presented in Fig. 5. The main metal constituents of the raw sludge were nickel $(\mathrm{Ni})$, iron $(\mathrm{Fe})$, alkali and alkaline earth metallic species (AAEMs) in terms of potassium (K), sodium (Na), calcium (Ca) and magnesium (Mg). Besides, these materials contain a certain content of silicon $(\mathrm{Si})$ and aluminum (Al). The contents of $\mathrm{Ni}$ and $\mathrm{Fe}$ for the hydrochar were higher than that of the pyrochar. It is reported that $\mathrm{Ni}$ and Fe can greatly catalyze the gasification process. Di Felice et al. [40] synthesized Fe and $\mathrm{Ni}$ doped alkaline-earth catalysts for biomass gasification. It was concluded that an enhanced hydrogen production was favored with the presence of Fe and Ni. Yan et al. [41] synthesized carbonencapsulated iron nanoparticles by thermal treatment of ironimpregnated pine char. It was observed that Fe significantly promoted the biochar decomposition. The high contents of AAEMs in biochar are also known to act as catalysts during the gasification process. Jiang et al. [42] reported that the presence of AAEMs promoted the heterogeneous char-steam reaction, hydrocarbons reforming and water-gas shift reactions during the steam

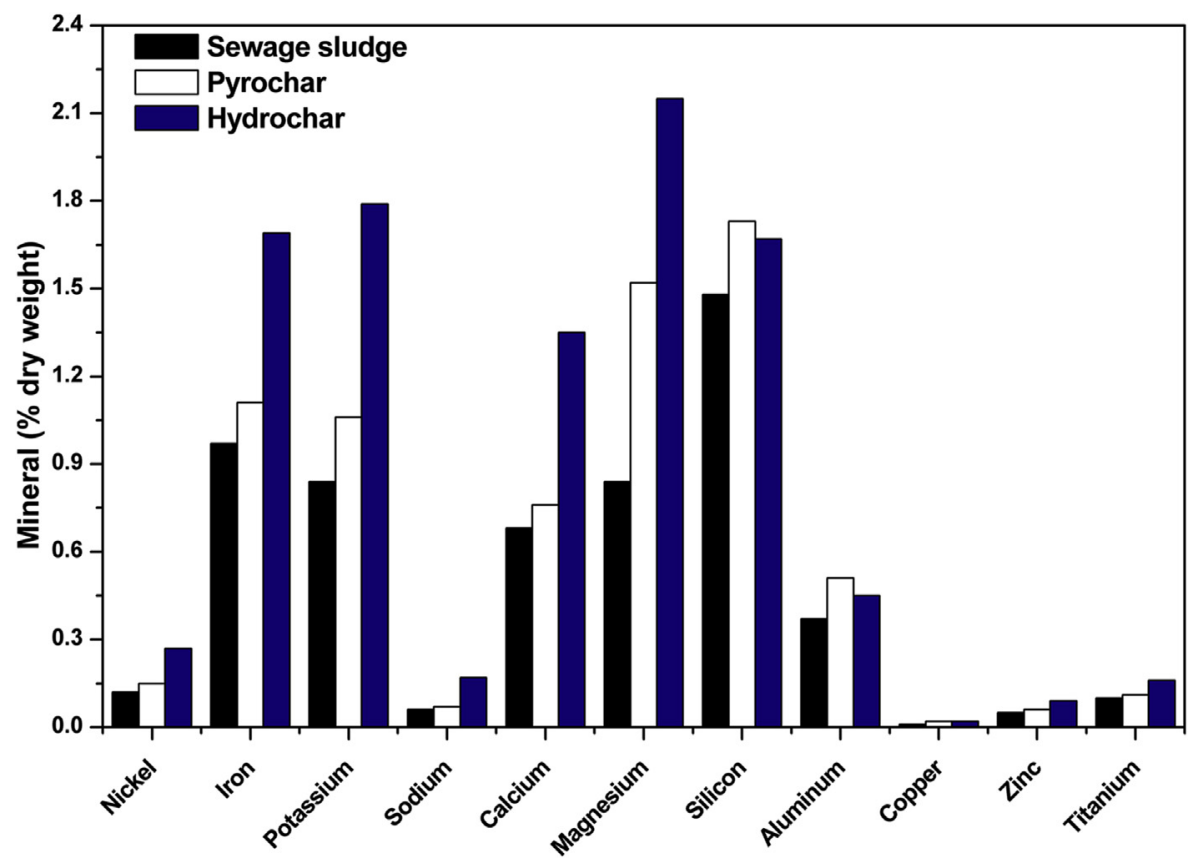

Fig. 5. Contents of inorganic elements of the pyrochar and hydrochar. 
gasification of biomass, and thus lead to an enhanced hydrogen concentration. However, a high content of $\mathrm{Si}$ and $\mathrm{Al}$ will inhibit the gasification process. To evaluate the overall catalytic effect on the gasification characteristics of the two biochars brought by the inorganic elements, a catalytic index $(\mathrm{CI})$ was calculated based on the literature [31]. It was determined by the ratio of sum of Fe and AAEMs which have a catalytic effect (e.g. K, Na, Mg, Ca) to the sum of inorganic elements, which have an inhibiting influence (e.g. Si, $\mathrm{Al}$ ). Based on the results in Fig. 5, the value of $\mathrm{CI}$ for the hydrochar was 3.37, which is higher than that of pyrochar (2.02) and raw sludge (1.83), indicating that the syngas quality and gasification efficiency of sewage sludge can be more enhanced by the pretreatment of HTC rather than LTP.

Another reason is the relatively high content of nitrogen in the hydrochar (see Table 1), which is mainly due to the protein-rich constituent of the raw sludge. Nitrogen atoms are inherently advantageous in interacting with hydrogen atoms than carbon atoms due to the presence of lone pair electrons, and thus promoted the interaction and reactivity. The basicity of biochar is closely related to resonating-electrons of carbon aromatic rings that attract protons and basic surface functionalities that are capable of binding with protons. For example, nitrogen functional groups (e.g., amides, imides, pyrrolic and pyridinic groups) in porous carbon materials provide basic properties and can enhance the interactions between the carbon surface and acid molecules like hydrogen bonding. Zhou [43] synthesized N-doped carbon-wrapped Co nanoparticles on Ndoped graphene nanosheets (Co-NC/NG) for hydrogen evolution reaction (HER). It was concluded that the non-noble-metal catalyst exhibited excellent hydrogen HER activity. Additionally, the oxygenated surface functional groups (e.g., carboxyls, lactones, phenols, and acid anhydrides) affect the acidity of the biochar. As indicated by FTIR (see Fig. 2), the $\mathrm{N}-\mathrm{H}$ bending of amide compounds in the hydrochar indicates the presence of nitrogen functionalities. In addition, the oxygenated surface functional groups in the pyrochar and hydrochar were decreased compared to the raw material. Therefore, it can be inferred that the acidities of the biochars derived from LTP and HTC pretreatment were both decreased and compared to the pyrochar, the hydrochar exhibited more basicity due to the more carbon aromatic rings and nitrogen functionalities. The surface chemical groups of the nitrogen-containing porous hydrochar may have the advantage of hydrogen production than the raw sludge and pyrochar. In addition, SEM images of the two biochars (see Fig. 2) presented that the structure of the hydrochar is partially destructed and more microspheres are formed on the surface of the hydrochar than that of the pyrochar. The porous structure of the hydrochar may facilitate the pores easily accessible for condensable hydrocarbon molecules and thus result in improved gas production and enhanced gasification efficiency.

\section{Conclusions}

In this study, two types of the biochars, pyrochar and hydrochar derived from sewage sludge have been prepared for hydrogen-rich gas production via steam gasification. The pyrochar was rich in aliphatic $\mathrm{C}-\mathrm{H}$ functional groups while more aromatic $\mathrm{C}-\mathrm{H}$ functional groups were presented in the hydrochar. Compared to the LTP-gasification method, the HTC pretreatment combined with subsequent gasification had a lower energy recovery efficiency of the whole process. However, the steam gasification of the hydrochar exhibited higher hydrogen concentration and yield as well as higher heating value, and gasification efficiency. The higher content of nickel, iron, alkali and alkaline earth metals and nitrogencontaining functional groups on the surface of the hydrochar mainly contributed to its excellent gasification property. In addition, compared to the pyrochar, the more porous structure of the hydrochar facilitated diffusion and transport of condensable hydrocarbon molecules during the gasification process. This study indicates that compared to low temperature pyrolysis, hydrothermal carbonization is a more effective pretreatment for enhancing hydrogen production from sewage sludge via steam gasification.

\section{Acknowledgements}

The authors gratefully acknowledge the financial support from the "100 Talents" Program of the Chinese Academy of Sciences to Zhengang Liu, Beijing Natural Science Foundation (Project No.8164064), Opening Project of Key Laboratory for Solid Waste Management and Environment Safety in Tsinghua University (Project No.SWMES 2015-13), and Key Laboratory of Solid Waste Treatment and Resource Recycle in Southwest University of Science and Technology (Project No. 15zxgk01).

\section{References}

[1] Kler AM, Tyurina EA, Potanina YM, Mednikov AS. Estimation of efficiency of using hydrogen and aluminum as environmentally-friendly energy carriers. Int J Hydrogen Energy 2015;40:14775-83.

[2] Cherad R, Onwudili JA, Biller P, Williams PT, Ross AB. Hydrogen production from the catalytic supercritical water gasification of process water generated from hydrothermal liquefaction of microalgae. Fuel 2016;166:24-8.

[3] Cieślik BM, Namieśnik J, Konieczka P. Review of sewage sludge management: standards, regulations and analytical methods. J Clean Prod 2015;90:1-15.

[4] Chiang KY, Chien KL, Lu CH. Characterization and comparison of biomass produced from various sources: suggestions for selection of pretreatment technologies in biomass-to-energy. Appl Energy 2012;100:164-71.

[5] Álvarez-Murillo A, Ledesma B, Román S, Sabio E, Gañán J. Biomass pyrolysis toward hydrocarbonization. Influence on subsequent steam gasification processes. J Anal Appl Pyrol 2015;113:380-9.

[6] Liu Z, Balasubramanian R. Upgrading of waste biomass by hydrothermal carbonization (HTC) and low temperature pyrolysis (LTP): a comparative evaluation. Appl Energy 2014;114:857-64.

[7] Liu W, Jiang H, Yu HQ. Development of biochar-based functional materials: toward a sustainable platform carbon material. Chem Rev 2015;115: $12251-85$.

[8] Sabio E, Álvarez-Murillo A, Román S, Ledesma B. Conversion of tomato-peel waste into solid fuel by hydrothermal carbonization: influence of the processing variables. Waste Manag 2016;47:122-32.

[9] Smith AM, Singh S, Ross AB. Fate of inorganic material during hydrothermal carbonization of biomass: influence of feedstock on combustion behavior of hydrochar. Fuel 2016;169:135-45.

[10] Minaret J, Dutta A. Comparison of liquid and vapor hydrothermal carbonization of corn husk for the use as a solid fuel. Bioresour Technol 2016;200: 804-11.

[11] Escala M, Zumbühl T, Koller C, Junge R, Krebs R. Hydrothermal carbonization as an energy-efficient alternative to established drying technologies for sewage sludge: a feasibility study on a laboratory scale. Energy Fuel 2013;27: 454-60.

[12] Kambo HS, Dutta A. A comparative review of biochar and hydrochar in terms of production, physico-chemical properties and applications. Renew Sust Energy Rev 2015;45:359-78.

[13] He C, Giannis A, Yang JY. Conversion of sewage sludge to clean solid fuel using hydrothermal carbonization: hydrochar fuel characteristics and combustion behavior. Appl Energy 2013;111:257-66.

[14] Erlach B, Harder B, Tsatsaronis G. Combined hydrothermal carbonization and gasification of biomass with carbon capture. Energy 2012;45:329-38.

[15] Gai C, Guo Y, Liu T, Peng N, Liu Z. Hydrogen-rich gas production by steam gasification of hydrochar derived from sewage sludge. Int J Hydrogen Energy 2016;41:3363-72.

[16] Hathaway BJ, Honda M, Kittelson DB, Davidson JH. Steam gasification of plant biomass using molten carbonate salts. Energy 2013;49:211-7.

[17] Stendardo S, Foscolo PU, Nobili M, Scaccia S. High quality syngas production via steam-oxygen blown bubbling fluidized bed gasifier. Energy 2016;103: 697-708.

[18] Lopez G, Alvarez J, Amutio M, Arregi A, Bilbao J, Olazar M. Assessment of steam gasification kinetics of the char from lignocellulosic biomass in a conical spouted bed reactor. Energy 2016;107:493-501.

[19] Kim D, Lee K, Park K. Hydrothermal carbonization of anaerobically digested sludge for solid fuel production and energy recovery. Fuel 2014;130:120-5.

[20] Danso-Boateng E, Holdich RG, Shama G, Wheatley AD, Sohail M, Martin SJ Kinetics of faecal biomass hydrothermal carbonisation for hydrochar production. Appl Energy 2013;111:351-7.

[21] Gai C, Dong Y. Experimental study on non-woody biomass gasification in a downdraft gasifier. Int J Hydrogen Energy 2012;37:4935-44. 
[22] Nipattummakul N, Ahmed I, Kerdsuwan S, Gupta AK. High temperature steam gasification of wastewater sludge. Appl Energy 2010;87:3729-34.

[23] Chen B, Zhou D, Zhu L. Transitional adsorption and partition of nonpolar and polar aromatic contaminants by biochars of pine needles with different pyrolytic temperatures. Environ Sci Technol 2008;42:5137-43.

[24] Yuan H, Lu T, Huang H, Zhao D, Kobayashi N, Chen Y. Influence of pyrolysis temperature on physical and chemical properties of biochar made from sewage sludge. J Anal Appl Pyrolsis 2015;112:284-9.

[25] Berge ND, Ro KS, Mao J, Flora JRV, Chappell MA, Bae S. Hydrotherma carbonization of municipal waste streams, Environ Sci Technol 2011:45: 5696-703.

[26] Funke A, Ziegler F. Hydrothermal carbonization of biomass; a summary and discussion of chemical mechanisms for process engineering. Biofuel Bioprod Biorg 2010;4:160-77.

[27] Wiedner K, Naisse C, Rumpel C, Pozzi A, Wieczorek P, Glaser B. Chemica modification of biomass residues during hydrothermal carbonization-What makes the difference, temperature or feedstock? Org Geochem 2013;54 $91-100$.

[28] Sereewatthanawut I, Prepintip S, Watchiraruji K, Goto M, Sasaki M Shotipruk A. Extraction of protein and amino acids from deoiled rice bran by subcritical water hydrolysis. Bioresour Technol 2008;99:555-61.

[29] Quitain AT, Faisal M, Kang K, Daimon H, Fujie K. Low-molecular-weight carboxylic acids produced from hydrothermal treatment of organic wastes. J Hazard Mater 2002;93:209-20.

[30] Rogalinski T, Liu K, Albrecht T, Brunner G. Hydrolysis kinetics of biopolymers in subcritical water. J Supercrit Fluid 2008;46:335-41.

[31] Bouraoui Z, Jeguirim M, Guizani C, Limousy L, Dupont C, Gadiou R. Thermogravimetric study on the influence of structural, textural and chemical properties of biomass chars on $\mathrm{CO}_{2}$ gasification reactivity. Energy 2015;88: 703-10.

[32] Zhao P, Shen Y, Ge S, Yoshikawa K. Energy recycling from sewage sludge by producing solid biofuel with hydrothermal carbonization. Energy Convers Manag 2014;78:815-21.

[33] Kambo HS, Dutta A. Comparative evaluation of torrefaction and hydrotherma carbonization of lignocellulosic biomass for the production of solid biofuel. Energy Convers Manag 2015;105:746-55.

[34] McBeath AV, Smernik RI, Schneider MPW, Schmidt MWI, Plant EL. Determination of the aromaticity and the degree of aromatic condensation of a thermosequence of wood charcoal using NMR. Org Geochem 2011;42: 1194-202.

[35] Stonor MR, Ferguson TE, Chen JG, Park AHA. Biomass conversion to $\mathrm{H}_{2}$ with substantially suppressed $\mathrm{CO}_{2}$ formation in the presence of Group I \& Group II hydroxides and a Ni/ZrO 2 catalyst. Energy Environ Sci 2015;8:1702-6.

[36] Fermoso J, Rubiera F, Chen D. Sorption enhanced catalytic steam gasification process: a direct route from lignocellulosic biomass to high purity hydrogen. Energy Environ Sci 2012;5:6358-67.

[37] Klaas M, Greenhalf C, Ferrante L, Briens C, Berruti F. Optimisation of hydrogen production by steam reforming of chars derived from lumber and agricultural residues. Int J Hydrogen Energy 2015;40:3642-7.

[38] Gao N, Li A, Quan C. A novel reforming method for hydrogen production from biomass steam gasification. Bioresour Technol 2009;100:4271-7.

[39] Palumbo AW, Sorli JC, Weimer AW. High temperature thermochemical processing of biomass and methane for high conversion and selectivity to $\mathrm{H}_{2}-$ enriched syngas. Appl Energy 2015;157:13-24.

[40] Di Felice L, Courson C, Ugo Foscolo P. Kiennemann A. Iron and nickel doped alkaline-earth catalysts for biomass gasification with simultaneous tar reformation and $\mathrm{CO}_{2}$ capture. Int J Hydrogen Energy 2011;36:5296-310.

[41] Yan Q Wan C, Liu J, Gao J, Yu F, Zhang J, et al. Iron nanoparticles in situ encapsulated in biochar-based carbon as an effective catalyst for the conversion of biomass-derived syngas to liquid hydrocarbons. Green Chem 2013; $15: 1631-40$

[42] Jiang L, Hu S, Wang Y, Su S, Sun L, Xu B, et al. Catalytic effects of inherent alkali and alkaline earth metallic species on steam gasification of biomass. Int J Hydrogen Energy 2015;40:15460-9.

[43] Zhou W, Zhou J, Zhou Y, Lu J, Zhou K, Yang L, et al. N-doped carbon-wrapped cobalt nanoparticles in N-doped graphene nanosheets for high-efficiency hydrogen production. Chem Mater 2015;27:2026-32.

\section{Nomenclature}

\section{LTP: Low temperature pyrolysis}

HTC: Hydrothermal carbonization

$T C D$ : Thermal conductivity detector

HHV: Higher heating value $(\mathrm{MJ} / \mathrm{kg})$

$L H V$ : Lower heating value $(\mathrm{MJ} / \mathrm{kg})$

VM: Volatile matter

FC: Fixed carbon

$S / B$ : Mass ratio of steam to biomass (-)

WGS: Water-gas shift reaction

AAEM: Alkaline earth metallic species

CI: Catalytic index

ERE: Energy recovery efficiency (-) 